Experimental allergic thyroiditis in rats: suppression by heterologous (rabbit) anti-lymphocyte sera to lymph node, thymic and splenic lymphocytes

R. N. M. MACSWEEN, K. ONO, P. R. F. BELL, CHARLOTTE M. THOMASON AND T. E. STARZL

\author{
Reprinted from \\ Clinical and Experimental Immunology \\ Vol. 6, No. 2, February 1970
}

BLACKWELL SCIENTIFIC PUBLICATIONS

OXFORD AND EDINBURGH 
Clin. exp. Immunol. (1970) 6, 273-278.

\title{
EXPERIMENTAL ALLERGIC THYROIDITIS IN RATS: SUPPRESSION BY HETEROLOGOUS (RABBIT) ANTI-LYMPHOCYTE SERA TO LYMPH NODE, THYMIC AND SPLENIC LYMPHOCYTES
}

\author{
R. N. M. MACSWEEN, K. ONO, P. R. F. BELL, \\ CHARLOTTE M. THOMASON AND T. E. STARZL \\ Departments of Pathology and Surgery, the University of Colorado \\ School of Medicine and the Veterans Administration Hospital, Denver, Colorado
}

(Received 5 August 1969)

SUMMARY

Heterologous (rabbit) anti-lymphocyte sera, raised by immunization with rat lymph node, thymic and splenic lymphocytes, have been shown to be of equal potency in suppressing experimental allergic thyroiditis in rats sensitized to allogeneic thyroid-adjuvant emulsion and pertussis vaccine.

\section{INTRODUCTION}

In a recent study (Ono et al., 1969) the relative immunosuppressive qualities of heterologous (rabbit) anti-lymphocyte (ALS) sera raised with rat lymphocytes from lymph nodes, thymus and spleen were determined. Using a test system of heterotopic cardiac transplantation, no inherent differences in the efficiency of these antisera could be detected.

In the present communication, an extension of these investigations is reported. Experimental allergic thyroiditis was produced in rats by the method of Paterson \& Drobish (1968), and the various rabbit antisera were evaluated for their ability to prevent the development of this iatrogenic disease.

\section{MATERIALS AND METHODS}

\section{Preparation of antisera}

The details of the ALS preparation have been previously reported (Ono et al., 1969). In brief, the three kinds of lymphocytes were removed from the lymph nodes, thymuses and spleens of inbred Fischer rats (purchased from Charles River Breeding Laboratories, Inc., Wilmington, Massachusetts), and given intravenously once a week for 4 weeks to New Zealand White rabbits to a total dose of approximately $3 \times 10^{8}$ cells. Blood was collected

Correspondence: Dr R. N. M. MacSween, Department of Pathology, The Western Infirmary, Glasgow, W.1, Scotland. 
by cardiac puncture 7 days after the fourth injection. Six rabbits contributed to a pool of each kind of antiserum. Before administration, the antisera were decomplemented by heating at $56^{\circ} \mathrm{C}$ for $30 \mathrm{~min}$ and then absorbed with rat platelets and rat red blood cells. For control studies, normal rabbit serum was collected and treated in the same way except that it was not submitted to absorption procedures.

After completion of the absorptions, the three antisera had similar lymphoagglutinin $(1: 1000)$, thymoagglutinin $(1: 1000)$ and lymphotoxicity $(1: 512)$ titres.

\section{Production of thyroiditis}

Commercially available Wistar and Sprague-Dawley frozen thyroid tissue (Pel-Freeze, Rogers, Arkansas) was thawed and homogenized in an equal volume of normal saline.

\begin{tabular}{|c|c|c|c|}
\hline Group & No. of rats & Sensitization (treatment) & $\begin{array}{c}\text { Histological evidence } \\
\text { of thyroiditis present } \\
\text { (No. of rats) }\end{array}$ \\
\hline A & Ten & $\begin{array}{l}\text { Thyroid-adjuvant } \\
\text { emulsion (saline) }\end{array}$ & Ten \\
\hline B & Ten & $\begin{array}{l}\text { Thyroid-adjuvant } \\
\text { emulsion (LNLAS) }\end{array}$ & One \\
\hline $\mathrm{C}$ & Ten & $\begin{array}{l}\text { Thyroid-adjuvant } \\
\text { emulsion (TLAS) }\end{array}$ & None \\
\hline $\mathrm{D}$ & Ten & $\begin{array}{l}\text { Thyroid-adjuvant } \\
\text { emulsion (SLAS) }\end{array}$ & None* \\
\hline $\mathrm{E}$ & Six & $\begin{array}{l}\text { Thyroid-adjuvant } \\
\text { emulsion (NRS) }\end{array}$ & Five \\
\hline $\mathrm{F}$ & Ten & $\begin{array}{l}\text { Saline-adjuvant } \\
\text { emulsion (none) }\end{array}$ & None \\
\hline
\end{tabular}

LNLAS, lymph node lymphocyte anti-serum; TLAS, thymus lymphocyte anti-serum; SLAS, spleen lymphocyte anti-serum; NRS, normal rabbit serum.

* One animal died during course of experiment.

The homogenate was emulsified with an equal volume of Freund's complete adjuvant (Difco Laboratories, Detroit, Michigan), and male 190-200-g Wistar-Furth rats (Microbiological Associates, Bethesda, Maryland) were injected once with the suspension. The dose was $0.1 \mathrm{ml}$ into the plantar surface of the right, hind foot. At the same time $0.1 \mathrm{ml}$ of a concentrated pertussis vaccine (supplied by Dr H. B. Devlin, Parke, Davis and Company, Detroit, Michigan) was injected into the dorsal surface of the same foot. In one group of control rats (Group F, Table 1) pertussis vaccine was given, but $0.1 \mathrm{ml}$ of a normal salineFreund's adjuvant emulsion was injected in place of the thyroid/adjuvant-emulsion.

\section{Treatment schedule}

There were six groups of test animals (Table 1), which received intraperitoneal therapeutic 
or control injections, commencing at the time of thyroid sensitization (day 0 ). The treatments were given on days $0,2,6,10$ and 15 , in individual doses of $1 \mathrm{ml}$.

Total white and lymphocyte counts were determined on tail vein blood before sensitization or the institution of treatment, and on postimmunization days 1, 3, 6, 8, 10 and 15 .

The rats were killed by bleeding out on day 17, and specimens of thyroid, spleen, lymph nodes and thymus were fixed in $10 \%$ neutral buffered formalin. The tissues were paraffin embedded, sections stained with haematoxylin and eosin, and microscopically examined without prior knowledge of the treatment. The degree of thyroiditis present was graded as follows: 0 , normal thyroid gland; + , mild focal thyroiditis; ++ , focal thyroiditis with minimal follicular destruction; +++ , diffuse extensive mononuclear cell infiltrate with accompanying follicular destruction.

\section{RESULTS}

\section{Haematological changes}

The peripheral lymphocyte counts in Groups A (saline treatment), E (normal rabbit serum) and $F$ (saline-adjuvant sensitization) showed an increase from days 3 to 8 with a

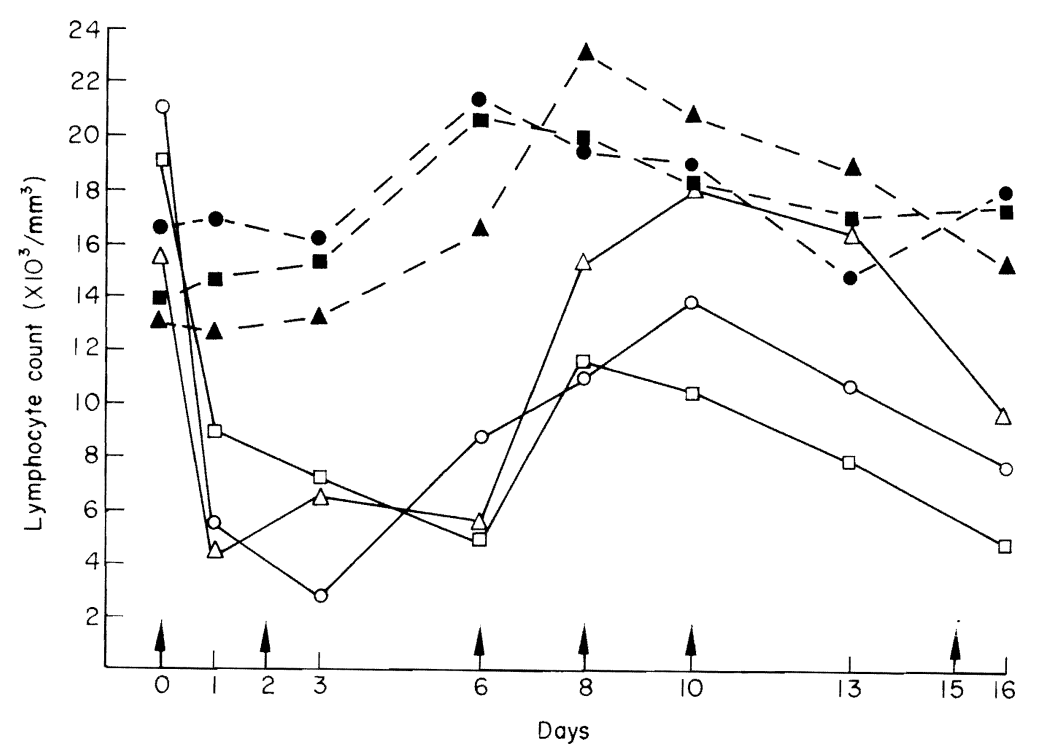

FIG. 1. The peripheral lymphocyte count in the various groups of rats: Arrows indicate days of treatments. $\bullet$ Saline treatment; $\bigcirc$, lymph node lymphocyte antiserum; $\square$, thymus lymphocyte antiserum; $\triangle$, spleen lymphocyte antiserum; $\mathbf{\Lambda}$, normal rabbit serum; $\boldsymbol{\square}$, no treatment.

steady decline thereafter (Fig. 1). The animals given the different antisera, however, invariably responded with a prompt and highly significant lymphopenia.

\section{The effect of therapy on thyroiditis}

When thyroid tissue was omitted from the sensitizing emulsion (Group F, Table 1), no lesions were seen in the thyroid glands of the treated animals. However, with inclusion of thyroid tissue, all ten animals treated with intraperitoneal saline had histological evidence of 


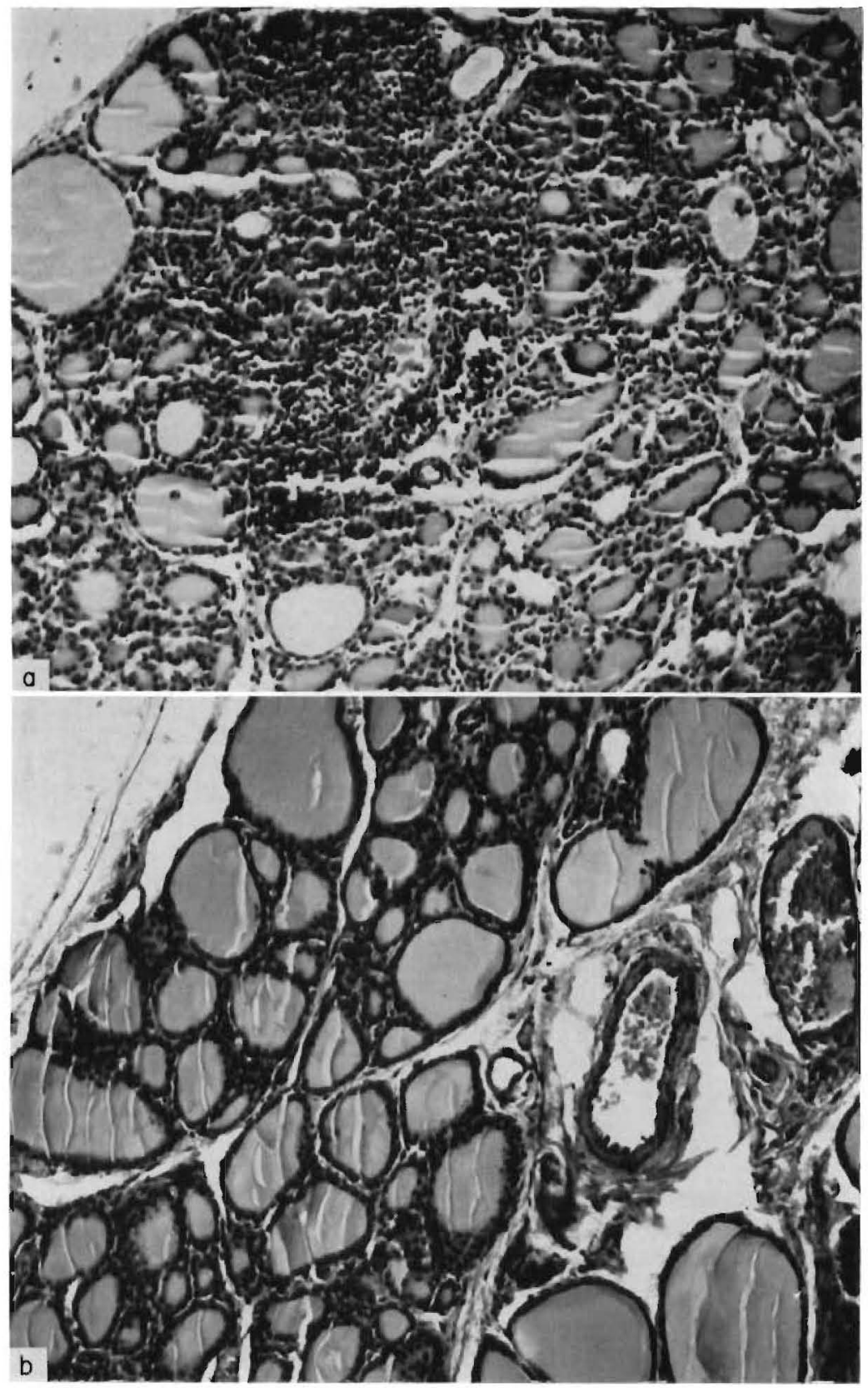

FIG. 2. Thyroid gland from rat immunized with thyroid-adjuvant emulsion, pertussis vaccine. (a) Treated with saline; there is a diffuse cellular infiltration of the gland with follicle destruction ( +++ thyroiditis). $H \& E, \times 160$. (b) Treated with thymus lymphoctye antiserum; the appearances are those of a normal gland. $\mathrm{H} \& \mathrm{E}, \times 160$. 
allergic thyroiditis (Fig. 2). The severity of the thyroiditis was +++ in five of these animals and the mean score for the ten was $2 \cdot 2$ plus. Similarly, five of the six rats treated with normal rabbit serum had thyroiditis, the mean plus score being $1 \cdot 8$.

In contrast (Table 1) microscopic changes in the thyroid were almost totally avoided in the twenty-nine rats who were given intraperitoneal ALS of one kind or another. In the entire group a diagnosis of thyroiditis was made only once. In this animal, which was treated with antiserum raised with lymph node lymphocytes, the lesion consisted of two small foci of thyroiditis.

The spleen, lymph nodes and thymuses from both control and treated animals showed no significant histological abnormalities.

\section{DISCUSSION}

Witebsky \& Rose (1956) first produced experimental allergic thyroiditis in rabbits by immunization with extracts of thyroid tissue emulsified in Freund's complete adjuvant. Using their technique, and with various modifications, allergic thyroiditis has been produced in rats by a number of other workers (Jones \& Roitt, 1961; Metzgar \& Grace, 1961; Biörklund, 1964). The deficiencies of these methods were that more than one immunization dose of thyroid-adjuvant emulsion was required, thyroid lesions were not uniformly produced and the thyroiditis was often relatively mild. Recently, Paterson \& Drobish (1968) described in rats an improvement in results if a concentrated pertussis vaccine was administered simultaneously with the thyroid-adjuvant emulsion. They were able to produce thyroiditis without fail, in a shorter time, and in a more severe form. The results in ALS untreated animals in our present investigations were similar to and confirmatory of those of Paterson \& Drobish (1968).

The value of ALS in preventing the onset of experimental autoimmune disease has been well established (James, 1967). The iatrogenic disorders which have been treated include allergic encephalomyelitis in guinea-pigs (Waksman, Arbouys \& Arnason, 1961; Leibowitz, Lessof \& Kennedy, 1968), adjuvant disease in rats (Currey \& Ziff, 1968), and allergic thyroiditis in rats (Kalden et al., 1968). In the present study the thyroiditis model was used as a means to assay the relative immunosuppressive activity of different kinds of ALS. Under the conditions of these experiments there appeared to be no difference in the efficacy of the antisera raised with lymph node, thymic or splenic lymphocytes. This finding was consistent with an earlier report from our laboratories in which the same three ALS products were tested for their ability to mitigate cardiac homograft rejection, and were shown to have equivalent potency (Ono et al., 1969). Although several other investigators have claimed to have produced a superior ALS with one kind or other of lymphoid tissue (Nagaya \& Sieker, 1965; Kubista, Hallenbeck \& Shorter, 1967), such differences have not been detectable in either variety of our controlled experiments.

\section{ACKNOWLEDGMENTS}

We wish to thank Dr H. B. Devlin, Parke, Davis and Company, Detroit, Michigan, for the generous supply of pertussis vaccine; and $\mathrm{Mr}$ Warren Boutchia for valuable technical assistance.

The work was supported by United States Public Health Service Grants CA-08804, AM-06344, AM-07772, FR-00051, ACI-04152, FR-00069, AM-12148 and AI-AM-08898. 


\section{REFERENCES}

BIöRKLUND, A. (1964) Testing in vitro of lymphoid cells from rats with experimental autoimmune thyroiditis. Lab. Invest. 13, 120.

Currey, H.L. \& ZiFF, M.P. (1968) Suppression of adjuvant disease in the rat by heterologous anti-lymphocyte globulin. J. exp. Med. 127, 185.

JAMES, K. (1967) Anti-lymphocytic antibody-a review. Clin. exp. Immunol. 2, 615.

JoNES, H.E.J. \& RoITT, I.M. (1961) Experimental auto-immune thyroiditis in the rat. Brit. J. exp. Path. 42, 546.

Kalden, J., James, K., Williamson, W.G. \& IRvine, W.J. (1968) The suppression of experimental thyroiditis in the rat by heterologous anti-lymphocyte globulin. Clin. exp. Immunol. 3, 973.

Kubista, T.P., Hallendeck, G.A. \& Shorter, R.G. (1967) Acceptance of Walker 256 tumor by mice receiving rabbit anti-mouse thymus serum (RAMTS). Fed. Proc. 26, 788.

LeIBOWITZ, S., Lessof, M.H. \& KenNedy, L.A. (1968) The effect of anti-lymphocyte serum on experimental allergic encephalomyelitis in the guinea-pig. Clin. exp. Immunol. 3, 753.

MetzGar, R.S. \& Grace, J.T. (1961) Production of experimental thyroiditis in rats and mice. Fed. Proc. 20, 39.

Nagaya, H. \& Sieker, H.O. (1965) Allograft survival: effect of antiserums to thymus glands and lymphocytes. Science, 150, 1181.

Ono, K., Bell, P.R.F., Kashiwagi, N. \& Starzl, T.E. (1969) The comparative in vitro and in vivo activity of ALS raised by immunization with thymic, splenic, and lymph node lymphocytes. Surgery, 66, 698.

Paterson, P.Y. \& Drobish, D.G. (1968) Rapid induction of experimental allergic thyroiditis in rats sensitized to thyroid/adjuvant and petussis vaccine. J. Immunol. 101, 1098.

Waksman, B.H., Arbouys, S. \& Arnason, B.G. (1961) The use of specific 'lymphocyte' antisera to inhibit hypersensitive reactions of the 'delayed' type. J. exp. Med. 114, 997.

Witebsky, E. \& Rose, N.R. (1956) Studies on organ specificity. IV. Production of rabbit thyroid antibodies in the rabbit. J. Immunol. 76, 408. 